\title{
ザゼンソウの恒温性を支配する負の活性化エネルギー 化学平衡の移動による体温调節の原理が明らかとなる
}

温度は生命現象に影響を与える大きな要因の一つであ る．温度の影響を回避するため，哺乳類および鳥類を含 む動物は，恒温性と呼ばれる自律性体温調節システムを 介し，外気温から独立した体温を維持している ${ }^{(1,2)}$. 動 物における恒温性は，神経系を介した複雑なメカニズム により達成されているが，興味深いことに，開花期特異 的な熱産生を行うある種の植物においてもこのような恒 温性が観察される。たとえば，早春の寒冷環境下で開花 するザゼンソウ (座禅草, 学名Symplocarpus renifolius）は，氷点下を含む外気温の変動においても，肉穂 花序と呼称される花器の温度を $23^{\circ} \mathrm{C}$ 内外に維持できる 恒温性を有している(3). ザゼンソウに扔いて観察される 恒温性は，肉穂花序の温度と逆相関を示す可逆的な呼吸 調節により達成される。本植物の呼吸調節が観察される 温度域（15 30 $\left.30^{\circ} \mathrm{C}\right)$ においては, 発熱器官である肉穂花 序の温度が低下すると呼吸速度が増大し, 逆に, 当該器 官の温度が上昇すると，その呼吸速度は低下する(4)。一 方, 肉穂花序温度が $15^{\circ} \mathrm{C}$ 未満の温度域では, 肉穂花序の 温度が低下すると呼吸速度も減少し，その恒温性は失わ れることが明らかとなっている．神経系をもたない植物に おける恒温性は，動物とは異なる制御メカニズムを有して いると考えられるが，その詳細は長い間不明のままであっ た．本稿においては，最近われわれが明らかにした本植 物の恒温性を支配するメカニズムについて紹介したい。

ザゼンソウの肉穂花序で観察される発熱は，炭水化物 を基質とする呼吸反応の立進により生じた代謝熱による ものである。呼吸を含む酸化反応は，通常は温度の上昇 とともにその反応速度が増大するが，上述したように， ザゼンソウ肉穂花序においては, 温度変化と逆相関を示 す呼吸調節メカニズムが存在する．われわれはこの問題 に対し，「肉穂花序における呼吸反応にかかわる活性化 エネルギー $\left(E_{0}\right)$ が, 温度変化によって特異的に変動 することにより本植物の恒温性が達成される」との仮説 に基づき，一連の実験と熱力学的解析を行った。具体的 には，フィールドに抏いて発熱している肉穂花序の温度 を 5 から $30^{\circ} \mathrm{C}$ の種々の温度に人為的に固定し，それぞれ の温度に扔ける呼吸速度を測定した。ささらに，得られた デー夕に対し， $E_{0}$ と温度との関連性を明らかにできる
修正アレニウスモデル(5)を適用した．その結果，ザゼン ソウ肉穂花序における呼吸反応にかかわる $E_{0}$ 值の算出 に成功するとともに，得られた $E_{0}$ 值が温度に対して動 的に変動し，本植物の恒温性が観察される呼吸調節範囲 に打いては，負の值を示すことを突き止めた ${ }^{(6)}$. 生物分 野に押いては，負の活性化エネルギーという概念はあま り馴染みのないものであるが，化学分野においては，負 の活性化エネルギーは温度上昇が化学反応速度の低下を 引き起こす反応において観察されることが知られてお り,この現象には前駆平衡と呼ばれる特異な化学平衡が 関与していることが報告されている(7)。これらの知見 は，負の活性化エネルギーが観察されたザゼンソウ肉穂

A

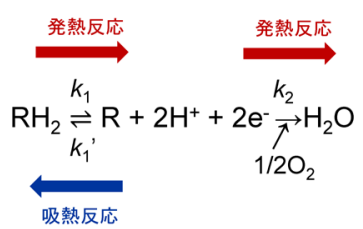

B

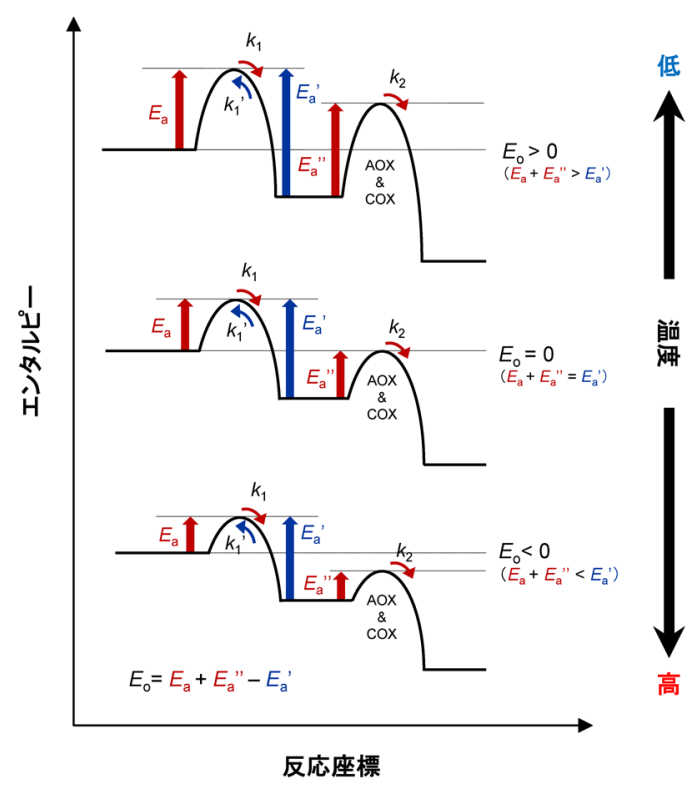

図1・ザゼンソウの恒温性にかかわる化学平衡

（A）前駆平衡反応．炭水化物を $\mathrm{RH}_{2}$ と表記している。（B）全体の 活性化エネルギー $\left(E_{0}\right)$ と温度との関倸. ザゼンソウの温度調節 域 $\left(15 \sim 30^{\circ} \mathrm{C}\right)$ に扔いて, $E_{0}$ は負の值を示す. 
花序においても, 前駆平衡反応に基づいた呼吸調節が行 われていることを示唆している.

前駆平衡反応は, 反応の速い可逆的反応と, その後の 不可逆的反応から構成される（図1A)。すなわち，発熱 反応および吸熱反応から構成される可逆的な反応が不安 定な中間体を形成し，その後の中間体を基質とした不可 逆的な反応が全体の反応速度を決定する。このような前 駆平衡反応においては，3つの活性化エネルギーが関与 している.すなわち，それぞれ $E_{\mathrm{a}}$ および $E_{\mathrm{a}}^{\prime}$ で示される 可逆的反応に抒ける発熱反応扮よび吸熱反応に関する活 性化エネルギーと， $E_{\mathrm{a}}^{\prime \prime}$ で示される不可逆的反応におけ る発熱反応の活性化エネルギーである（図1B）。ここ で，全体の活性化エネルギーである $E_{0}$ は，温度により 個別に変化する $E_{\mathrm{a}}, E_{\mathrm{a}}^{\prime}$ ，および $E_{\mathrm{a}}^{\prime \prime}$ の相対的な大きさに よって以下のように決定される.

$$
E_{0}=E_{\mathrm{a}}+E_{\mathrm{a}}^{\prime \prime}-E_{\mathrm{a}}^{\prime}
$$

ここに示す前駆平衡反応において， $E_{0}$ が正の值を示す 場合 $\left(E_{\mathrm{a}}+E_{\mathrm{a}}^{\prime \prime}>E_{\mathrm{a}}^{\prime}\right)$, 反応系の温度が上昇すると, 個別 の活性化エネルギーの值が小さくなることで $E_{0}$ 值も低 下し，全体の反応速度は上昇する．やがて温度上昇によ り $E_{0}$ 值がゼロになると, 反応の障壁となる全体の活性 化エネルギーが最小となることから, 反応速度が最大と なる，一方，反応系の温度がさらに上昇すると， $E_{0}$ が 負の值を示し $\left(E_{\mathrm{a}}+E_{\mathrm{a}}^{\prime \prime}<E_{\mathrm{a}}^{\prime}\right)$, 吸熱反応の影響が大きく なり, 化学平衡が左に移動し, 全体の反応速度は低下す る. 先述のと抒り, ザゼンソウ肉穂花序に抒ける呼吸は 炭水化物を基質としていることから，本植物の熱制御に かかわる呼吸反応は脱水素酵素を介した可逆的反応と, それにより生じる電子を用いたミトコンドリア末端呼吸 酵素 (AOX：シアン耐性呼吸酵素, および, COX：チ トクローム $c$ オキシダーゼ）を介した不可逆的な酸化反 応が前駆平衡を構成していると考えられる.

さらに，われわれは，負の活性化エネルギーが生じる 実験系をin vitroに抢いて再構成することを目的に，ザ ゼンソウ発熱組織から単離したミトコンドリアを用いた 呼吸解析を行った？その結果，前駆平衡に基づく呼吸反 応を再構成した場合においてのみ, 負の活性化エネル ギーが特異的に観察されることが判明した ${ }^{(6)}$.また，in vitroにおける再構成系における前駆平衡の形成には, ミトコンドリアのマトリクス内でNADPH 産生にかかわ るイソクエン酸デヒドロゲナーゼによる吸熱反応が重要

\section{今日の話題}

であることが示された．さらに，AOXおよびCOXを介 したそれぞれの呼吸経路の温度感受性を解析したとこ

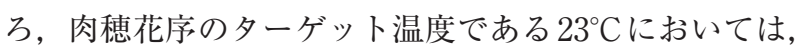
AOX 経路がより高い温度感受性を示すことが判明した。 ATP合成に関与しないAOXを介した酸素消費は熱散逸 的に働くことから，熱産生への関与が指摘されている が(8)，AOXが触媒する呼吸はザゼンソウの恒温性にお いても重要な機能を有していることが考えられる.

以上のように，ザゼンソウの恒温性においては，発熱 反応のみならず吸熱反応を含む化学平衡が重要な役割を 担っている. 従来の植物の熱制御にかかわる研究は, 発 熱反応と温度との関係の解明に主眼を置くものであった が，今回，ザゼンソウの恒温性メカニズムに打ける吸熱 反応の重要性が明らかとなったことは, 従来にはない新 しい視点である。 また, 温度変化は化学平衡の平衡点の シフトを引き起こすことから, 本メカニズムは, 植物の 熱制御のみならず，より広範囲の生命現象において温度 センシングメカニズムとしても機能している可能性が考 えられる.

ザゼンソウ肉穂花序で観察される恒温性は, Zazen attractorで特徴づけられる決定論的現象である ${ }^{(9)}$. 今回 明らかとなった負の活性化エネルギーがZazen attractorを生み出すメカニズムにいかにかかわっているかと いう点も, 今後の興味ある問題である.

1) R. R. J. Chaffee \& J. C. Roberts: Annu. Rev. Physiol., 33, 155 (1971).

2) S. F. Morrison \& K. Nakamura: Front. Biosci., 16, 74 (2011).

3) R. S. Seymour, Y. Ito, Y. Onda \& K. Ito: Biol. Lett., 5, 568 (2009).

4) R. S. Seymour, G. Lindshau \& K. Ito: Planta, 231, 1291 (2010).

5) J. Kruse, H. Rennenberg \& M. A. Adams: New Phytol., 189, 659 (2011).

6) Y. Umekawa, R. S. Seymour \& K. Ito: Sci. Rep., 6, 24830 (2016).

7) U. Maharaj \& M. A. Winnik: J. Am. Chem. Soc., 103, $2328(1981)$.

8) A. L. Moore, T. Shiba, L. Young, S. Harada, K. Kita \& K. Ito: Annu. Rev. Plant Biol., 64, 637 (2013).

9) T. Ito \& K. Ito: Phys. Rev. E Stat. Nonlin. Soft Matter Phys., 72, 051909 (2005).

$($ 梅川 結*1, 伊藤菊一 $* 2$, $* 1$ 岩手大学農学部特任研究 員, *2岩手大学農学部応用生物化学科・附属寒冷バイ オフロンティア研究センター) 


\section{今日の話題}

プロフィール

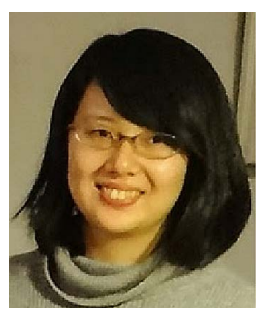

梅 川 結 (Yui UMEKAWA)

<略歴>2012年岩手大学農学部応用生物 化学課程卒業/2014年同大学院農学研究 科修士課程修了 $/ 2017$ 年同院連合農学研 究科博士課程修了/同年同農学部特任研究 員, 現在に至る<研究テーマと抱負 $>$ 生命 現象を, 化学平衡の動的変化を含めた非平 衡系にかかわる理論を用いて理解したい <趣味>読書, ギター，地場産品をみるこ と

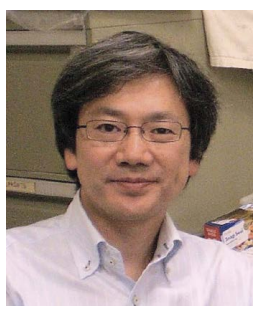

伊藤 菊一（Kikukatsu ITO）

<略歴>1986年岩手大学農学部農芸化学 科卒業 / 1988 年同大学院農学研究科農芸 化学専攻修士課程修了／1991年山形大学 大学院医学研究科博士課程中退 /同年同大 学医学部第 2 生化学助手 $/ 1994$ 年岩手大学 農学部助手 $/ 1998$ 年同農学部講師 $/ 2000$ 年同農学部助教授 $/ 2006$ 年同農学部教授, 現在に至る. 1994年医博 (山形大学) <研 究テーマと抱負 >生物のホメオスタシスの 背後にある原理を解き明かすこと<趣味 $>$ クラシック音楽鑑賞

Copyright (C) 2017 公益社団法人日本農芸化学会 DOI: 10.1271/kagakutoseibutsu.55.520 